\title{
WORKSHOP GURU BERPRESTASI BAGI GURU SD DAN SMP LINGKUP DINAS PENDIDIKAN DAN KEBUDAYAAN KOTA BAUBAU
}

Erny Harijaty ${ }^{1}$, Fina Amalia Masri², Nanik Indaryanti Ningsih ${ }^{3}$, Elmy Selfiana Malik ${ }^{4}$

${ }^{1}$ Jurusan Pendidikan Bahasa dan Sastra Indonesia dan Daerah FKIP Universitas Halu Oleo, email: ernyharijaty@gmail.com

3Jurusan Pendidikan Ekonomi FKIP Universitas Halu Oleo, email: nani_unhalu@yahoo.co.id

2,4Jurusan Bahasa dan Sastra, Universitas Halu Oleo, email: finaamaliamasri@gmail.com

Alamat email korespondensi: finaamaliamasri@gmail.com

\section{RINGKASAN}

Kompetensi dan profesionalisme seorang guru patut ditingkatkan karena imbasnya adalah kualitas atau mutu siswa, utamanya di era revolusi industri 4.0 yang menuntut daya saing tinggi. Salah satu upaya untuk meningkatkan kompetensi dan profesionalisme guru adalah melalui pelaksanaan lomba guru berprestasi. Akan tetapi, berbagai kendala menyebabkan kurangnya minat para guru untuk berkompetisi dalam lomba tersebut diantaranya adalah di Kota Baubau. Oleh karena itu, tim pengabdian berupaya untuk mengatasinya melalui workshop guru berprestasi bagi guru SD dan SMP lingkup Dinas Pendidikan dan Kebudayaan Kota Baubau. Workshop ini dilaksanakan dengan memperhatikan Juknis Guru Berprestasi SD dan SMP tahun 2019. Pada hasil workshop tersebut terlihat 21 orang guru kurang mengetahui tentang jenis karya yang dihasilkan sebagai salah satu syarat untuk menjadi guru berprestasi dan 27 orang guru kurang mengetahui tentang persyaratan pemilihan guru berprestasi. Pada akhir pelaksanaan workshop ini, kesulitan peserta dalam menyusun portofolio berkurang menjadi hanya 2 orang guru. Sementara guru yang kesulitan menulis karya tulis ilmiah berupa best practise dan PTK berkurang menjadi 11 orang, serta yang kesulitan membuat video pembelajaran berkurang menjadi 5 guru. Selain itu, guru yang kesulitan membuat PKG (Penilaian Kinerja Guru) berkurang menjadi 6 orang.

\section{Kata Kunci: Guru Berprestasi; Guru SD dan SMP; Kota Baubau}

\section{A. Latar Belakang}

Dunia pendidikan di Indonesia saat ini sedang diperhadapkan oleh tuntutan untuk menyinergikan pembelajarannya dengan kemajuan dan efektifitas pencapaian output yang sesuai dengan kemajuan teknologi berdasar revolusi industri 4.0. Kemajuan peradaban ini tidak dapat dipungkiri juga berimbas pada percepatan progress berbagai lini kehidupan yang salah satunya pendidikan di sekolah. Objek yang disasar pencapaian progress tidak hanya siswa sebagai sentra penerus cita-cita bangsa, tetapi juga para guru 
yang menjembatani tercapainya kehidupan bangsa yang cerdas secara akademik maupun psikis.

Menjawab tuntutan revolusi industri 4.0, guru diperhadapkan dengan sejumlah kewajiban yang mengantarnya pada peningkatan kompetensi. Sebagaimana yang dikatakan oleh Dante (2009) bahwa bila dikaji lebih dalam situasi pendidikan masa depan dan bagaimana peran guru sebagai pengemban paradigma pendidikan yang berpusat pada pembelajaran, maka kualifikasi dan kompetensi guru sebagai pemangku jabatan ahli haruslah menjadi salah satu fokus utama. Meningkatnya kompetensi juga harus berbanding lurus dengan profesionalisme kerja guru. Berdasarkan UU Nomor 14 tahun 2005 tentang guru dan dosen, bahwa dalam melaksanakan tugas keprofesionalan, guru berkewajiban untuk 1) Merencanakan pembelajaran, melaksanakan proses pembelajaran yang bermutu, serta menilai dan mengevaluasi hasil pembelajaran, 2) Meningkatkan dan mengembangkan kualifikasi akademik dan kompetensi secara berkelanjutan sejalan dengan perkembangan ilmu pengetahuan, teknologi, dan seni. 3) Bertindak objektif dan tidak diskriminatif atas dasar pertimbangan jenis kelamin, agama, suku, ras, dan kondisi fisik tertentu, atau latar belakang keluarga, dan status sosial ekonomi peserta didik dalam pembelajaran. 4) Menjunjung tinggi peraturan perundang-undangan, hukum, dan kode etik guru, serta nilai-nilai agama dan etika.

Selain kewajiban tersebut, guru juga diperhadapkan dengan berbagai masalah terkait peserta didik di sekolah masing-masing. Oleh karena itu, diperlukan keseimbangan dalam menjalankan kewajiban dengan hak-hak guru yang salah satunya adalah pemberian reward. Pemberian reward atas dedikasi guru dapat memungkinkan peningkatan profesionalitas yang berujung pada peningkatan pendidikan nasional. Hal ini sesuai amanat Undang-Undang Republik Indonesia Nomor 14 Tahun 2005 tentang Guru dan Dosen, Pasal 36 ayat (1) bahwa "Guru yang berprestasi, berdedikasi luar biasa, dan/atau bertugas di daerah khusus berhak memperoleh penghargaan" dan berdasarkan Peraturan Pemerintah Republik Indonesia Nomor 74 Tahun 2008 Pasal 30 ayat (1) bahwa 
"Guru memiliki hak untuk mendapatkan penghargaan sesuai dengan prestasi kerja, dedikasi luar biasa, dan/atau bertugas di Daerah Khusus".

Di Kota Baubau, para guru yang tercatat sebagai peserta lomba guru berprestasi dapat dikatakan sangat sedikit. Setidaknya dapat dilihat pada jumlah keikutsertaan guru berprestasi 2 (dua) tahun terakhir, yakni tahun 2018 sebanyak 6 orang dan tahun 2019 hanya berjumlah 7 orang (Dinas Pendidikan dan Kebudayaan Kota Baubau, 2019). Jumlah yang cukup timpang jika dibandingkan dengan jumlah keseluruhan guru di Kota Baubau serta berbagai masalah yang mampu diselesaikan guru-guru tersebut sehingga dikatakan layak untuk memperoleh sebuah "reward". Oleh karena itu, diperlukan usaha peningkatan jumlah guru berprestasi di Kota Baubau sehingga mitra dari pengabdian kepada masyarakat ini adalah Dinas Pendidikan dan Kebudayaan Kota Baubau.

Mitra dari Pengabdian kepada masyarakat yang dilakukan tim pengabdian ini difokuskan kepada guru-guru SD dan SMP dibawah koordinasi Dinas Pendidikan dan Kebudayaan Kota Baubau. Jumlah guru SD di Kota Baubau berdasarkan data dari Badan Pusat Statistik tahun 2018/2019 adalah 17.765 orang dan jumlah guru SMP di Kota Baubau adalah 726 orang. Dari permasalah tersebut kemudian tim pengabdian membuat workshop sebagai upaya mengatasi kurangnya minat guru SD dan SMP lingkup Dinas Pendidikan dan kebudayaan Kota Baubau terhadap lomba guru berprestasi.

\section{B. Metode Pelaksanaan}

\subsection{Sasaran Pengabdian}

Kegiatan ini menyasar guru-guru SD dan SMP se-Kota Baubau sehingga mitra tim pengabdi dalam kegiatan ini adalah Dinas Pendikan dan Kebudayaan Kota Baubau. Dalam kegiatan ini, partisipasi mitra adalah mewadahi terselenggaranya kegiatan dengan menyasar guru SD dan SMP se Kota Baubau sehingga terdapat peningkatan terhadap peminat sebagai peserta guru berprestasi yang mewakili Kota Baubau.

\subsection{Tahapan Pelaksanaan Kegiatan}

Pelaksanaan kegiatan pengabdian kepada masyarakat ini dilakukan melalui beberapa tahap yakni persiapan dan pelaksanaan workshop. 
Tahap persiapan dilakukan dengan cara: 1) tim peneliti membuat pernyataan kerjasama dengan pihak Dinas Pendidikan dan Kebudayaan Kota Baubau. 2) mendata jumlah SD dan SMP di Kota Baubau. 3) Mendata guru-guru SD dan SMP yang aktual di Kota Baubau. 4) Menentukan tempat workshop yang dapat menampung para peserta yang terdiri dari guru-guru SD dan SMP se Kota Baubau, 5) membuat dan menyebarkan undangan workshop, serta 6) mempersiapkan ruangan untuk melakukan workshop tersebut.

Tahap pelaksanaan melalui beberapa tahap, yakni: 1) memberi informasi terkait capaian dan peringkat kualitas pendidikan di Kota Baubau, 2) memberi penguatan tentang pentingnya guru berprestasi bagi peningkatan kualitas pendidikan di Kota Baubau, 3) Mensosialisasikan pedoman guru berprestasi terupdate dengan terlebih dahulu mengemukakan kriteria guru berprestasi dan cara memenuhi kriteria-kriteria tersebut, 4) Menjelaskan pembobotan di tingkat kabupaten/ Kotayang terdiri dari dokumen portofolio, penilaian kinerja guru, tes tulis, karya tulis ilmiah dan artikel, presentasi artikel ilmiah dan tanya jawab, keteladanan dan akhlak mulia, 5) melakukan diskusi atau tanya jawab terkait workshop tersebut.

\section{Hasil dan Pembahasan}

Kegiatan ini dilaksanakan dalam rangka pengabdian kepada masyarakat yang merupakan salah satu dari perwujudan Tridharma Perguruan Tinggi yang pelaksanaannya dilatarbelakangi oleh keprihatinan tim melihat fenomena dari tahun ke tahun jumlah peserta yang mengikuti lomba guru berprestasi sangat sedikit jumlahnya. Guru SD dan SMP kurang tertarik untuk mengikuti lomba guru berprestasi. Demikian pula Kepala SD dan SMP beserta para pengawas kurang tertarik untuk mengikutinya.

Untuk tahun 2019 jumlah peserta untuk tingkat SD hanya empat orang, guru SMP hanya dua orang, Kepala SMP hanya satu orang. Sementara Kepala SMP dan pengawas tidak ada pesertanya. Hal ini sangat memprihatinkan, karena lomba ini adalah lomba yang setiap tahun diadakan dari satuan pendidikan sampai ke tingkat nasional. Pihak dinas pendidikan pun telah mengapresiasi kegiatan Gurpres ini dengan memberikan hadiah berupa uang bagi peserta yang memperoleh juara satu sampai dengan juara tiga dan disertakan pula untuk mengikuti studi banding bersama dengan siswa-siswa yang 
berprestasi. Tujuan diadakan lomba guru berprestasi adalah untuk peningkatan motivasi dan profesionalisme guru dalam pelaksanaan tugas profesionalitasnya.

\section{Workshop sebagai Upaya Mengatasi Kurangnya Minat Guru SD dan SMP Lingkup Dinas Pendidikan dan Kebudayaan Kota Baubau terhadap Lomba Guru Berprestasi}

Kurangnya Minat Guru SD dan SMP Lingkup Dinas Pendidikan dan Kebudayaan Kota Baubau terhadap Lomba Guru Berprestasi dapat di atasi melalui workshop yang didalamnya terdapat manfaat untuk memotivasi kepala sekolah, pengawas, dan guru agar mereka dapat meningkatkan kinerja, disiplin, dedikasi, dan loyalitasnya demi tercapinya tujuan pendidikan yang semakin berkualitas.

Melihat fenomena kurangnya jumlah peserta yang mengikuti lomba guru berprestasi tingkat SD dan SMP di Kota Baubau maka tim pengabdian kepada masyarakat melaksanakan workshop Guru Berprestasi bagi Guru SD dan SMP di Lingkup Dinas Pendidikan dan Kebudayaan Kota Baubau untuk mencari solusi dari permasalahan tersebut.

Sebelum pelaksanaan workshop guru berprestasi bagi guru SD dan SMP di lingkup Dinas Pendidikan dan Kebudayaan Kota Baubau, tim bersurat kepada Kepala Dinas Pendidikan dan Kebudayaan Kota Baubau bahwa proposal pengabdian kepada masyarakat internal UHO dimana Diknas Kota Baubau sebagai mitra telah dinyatakan lolos seleksi sehingga siap untuk dilaksanakan. Oleh karena itu, pihak Diknas Kota Baubau membantu tim untuk mempersiapkan pelaksanaan workshop guru berprestasi sesuai dengan proposal yang telah diajukan tim kepada LPPM UHO beberapa waktu yang lalu. Pada tahap persiapan, tim membuat surat peminjaman gedung Aula Dinas Pendidikan dan Kebudayaan Kota Baubau untuk pemakaian tanggal 11 September 2019 pukul 08.00 wita sampai dengan pukul 13.00 wita.

Workshop guru berprestasi bagi guru SD dan SMP di lingkup Dinas Pendidikan dan Kebudayaan Kota Baubau diikuti oleh 69 orang guru SD dan SMP serta kepala sekolah di Lingkup Dinas Pendidikan dan Kebudayaan Kota Baubau. Minat guru-guru di Kota 
Baubau ternyata sangat besar terhadap lomba guru berprestasi dengan melihat banyaknya jumlah peserta yang mengikuti kegiatan ini.

Dalam Workshop ini, peserta diberikan materi tentang pedoman pemilihan guru berprestasi tingkat nasional yang meliputi pengertian guru berprestasi, prestasi atau karya yang dihasilkan untuk sebagai salah satu syarat untuk menjadi guru berprestasi, dan persyaratan pemilihan guru berprestasi yakni persyaratan akademik, persyaratan administratif, serta persyaratan khusus.

\section{Faktor-faktor Penyebab Kurangnya Minat Guru SD dan SMP Lingkup Dinas Pendidikan dan Kebudayaan Kota Baubau terhadap Lomba Guru Berprestasi}

Faktor-faktor penyebab tersebut dapat dilihat pada saat dimulainya kegiatan workshop dimana tim pelaksana bertanya kepada peserta melalui tanya jawab sebelum dimulainya materi. Dari kegiatan tanya jawab tersebut diperoleh hasil berupa jumlah peserta yang kurang mengetahui tentang pedoman pemilihan guru berprestasi tingkat nasional berjumlah 48 orang, dengan rincian sebagai berikut:

1. 21 orang guru kurang mengetahui tentang jenis karya yang dihasilkan sebagai salah satu syarat untuk menjadi guru berprestasi.

2. 27 orang guru kurang mengetahui tentang persyaratan pemilihan guru berprestasi.

Hasil yang telah dicapai setelah pelaksanaan workshop ini yaitu dapat dikatakan hampir seluruh peserta yang mengikuti kegiatan ini telah mengetahui pedoman pemilihan guru berprestasi tingkat nasional. Pada pelaksanaan workshop ini juga terlihat 7 orang guru yang kesulitan dalam menyusun portofolio, 21 orang guru yang kesulitan menulis karya tulis ilmiah berupa best practice atau Penelitian Tindakan Kelas, 13 orang guru yang kesulitan membuat video pembelajaran, dan 9 orang guru yang kesulitan membuat PKG (Penilaian Kinerja Guru).

Pada akhir pelaksanaan workshop ini, kesulitan peserta dalam menyusun portofolio berkurang menjadi hanya 2 orang guru. Sementara guru yang kesulitan menulis karya tulis ilmiah berupa best practise dan PTK berkurang menjadi 11 orang, serta yang 
kesulitan membuat video pembelajaran berkurang menjadi 5 guru. Selain itu, guru yang kesulitan membuat PKG (Penilaian Kinerja Guru) berkurang menjadi 6 orang.

Berdasarkan hasil pelaksanaan workshop di atas, diketahui penyebab sehingga guru tidak tertarik untuk mengikuti lomba guru berprestasi yakni karena kurang jelasnya informasi yang diperoleh terkait jadwal pelaksanaan dan kurangnya persiapan serta pemahaman terkait guru berprestasi. Selain itu, penyampaian dari pihak Dinas Pendidikan dan Kebudayaan Kota Baubau dikatakan terlalu mendadak sehingga guru-guru tidak sempat untuk melakukan persiapan baik berkas sebagai syarat mengikuti lomba guru berprestasi. Melalui beberapa surat edaran dari kemendikbud, pemateri memperlihatkan jadwal pengusulan guru berprestasi hingga diadakannya lomba guru berprestasi yaitu pelaksanaannya sekitar bulan Maret sampai dengan Mei setiap tahunnya. Melihat hal tersebut, dibutuhkan perhatian tidak hanya oleh Dinas Pendidikan dan Kebudayaan, tetapi juga dibutuhkan perekrutan guru berprestasi tingkat sekolah masing-masing termasuk juga diperlukan kesiapan masing-masing individu guru yang dapat mengikuti lomba guru berprestasi.

\section{Kesimpulan}

Peningkatan kompetensi dan profesionalisme guru dilakukan melalui kegiatan workshop guru berprestasi. Hal mendasar penyelenggaran kegiatan ini adalah kurangnya sosialisasi pedoman guru berprestasi tingkat nasional. Maka, kegiatan ini memotivasi kepala sekolah, pengawas, dan guru agar mereka dapat meningkatkan kinerja, disiplin, dedikasi, dan loyalitasnya demi tercapinya tujuan pendidikan yang semakin berkualitas. Olehnya itu, kegiatan ini memberi dampak terhadap peningaktan pemahaman terhadap pedoman tersebut serta membutuhkan perhatian serius dinas terkait agar guru mampu bersaing di kancah nasional.

\section{E. UCAPAN TERIMAKASIH}

Kami menyampaikan terima kasih kepada seluruh pihak yang terlibat pada kegiatan Pengabdian Kepada masyarakat ini atas bantuannya selama kegiatan sehingga bisa berjalan lancar. 


\section{DAFTAR PUSTAKA}

Arikunto, Suharsimi. 1996. Pengelolaan Kelas dan Siswa, Sebuah Pendekatan Evaluatif. Jakarta: PT Raja Grasindo.

Asep, Jihad dan Suyanto. 2013. Menjadi Guru Profesional. Jakarta: Erlangga.

Daeng, Arifin, Dadi dan Permadi. 2013. Panduan Menjadi Guru Profesional. Bandung: CV Nuansa Aulia.

Emha, Hendra Ainun Najib. 2014. Regulasi Diri dan Perrjalanan Karir Guru PAI Berprestasi. Skripsi UIN Sunan Kalijaga: Yogyakarta.

Ginting, Abudrrahman. 2010. Esensi Praktis Belajar dan Pembelajaran. Bandung: Humaniora.

Hasbullah. 2006. Dasar-dasar IImu Pendidikan. Jakarta: Raja Grafindo Persada.

Hermawan. 2013. Pengembangan Sistem Pendukung Keputusan Pemilihan Guru Berprestasi. Skripsi UIN Sunan Kalijaga Yogyakarta.

Nurfuadi. 2012. Profesionalisme Guru. Purwokerto: STAIN Press.

Sutikno, Agus. 2013. Portofolio Guru Berprestasi SD Negeri Lempuyangan 1 KotaYogyakarta. 